\title{
Analisis Penentuan Waktu Standar Pada Proses Outbond Bagasi di PT Angkasa Pura II
}

\author{
Noneng Nurjanah'), Nur Rahma Ba'tha ${ }^{2)}$ \\ 1)D-III Administrasi Logistik, Politeknik Pos Indonesia \\ Email noneng.nurjanah@gmail.com \\ 2)D-III Administrasi Logistik, Politeknik Pos Indonesia \\ Email nurrahmabatha123@gmail.com
}

\begin{abstract}
Abstrak
Time Study merupakan suatu usaha untuk menentukan lamanya waktu kerja yang diperlukan oleh seorang operator untuk menyelesaikan suatu pekerjaan (Niebel, 1988). Pengukuran waktu secara garis besar terdiri dari 2 jenis, yaitu pengukuran waktu langsung dan pengukuran waktu tidak langsung. Untuk menghitung waktu standar perlu dihitung waktu siklus rata-rata yang disebut dengan waktu terpilih, rating factor, waktu normal dan kelonggaran (allowance). dilakukan untuk meramalkan kejadian yang terjadi pada masa depan. Penelitian mengenai peramlan Dengan demikian waktu efektif atau waktu standar yang mampu dilakukan oleh setiap Ground Handling dalam melakukan penyediaan jasa sangat dibutuhkan oleh penumpang. Penyimpangan layanan bagasi tersebut biasa terjadi pada saat penumpang tiba di stasiun tujuan akhir atau saat post flight services, hal tersebut bisa menjadi salah satu tolak ukur kinerja suatu Ground Handling, baik atau tidaknya dalam memberikan layanan kepada penumpang. Kasus-kasus yang berhubungan dengan penyimpangan bagasi tersebut masih menggunakan proses manual yang pada akhirnya memakan waktu yang cukup lama. Maka dengan demikian, penggunaan metode Time Study yang dilakukan oleh penulis berguna untuk menganalisis penyebab terjadinya keterlambatan dan juga mendapatkan solusi yang tepat agar proses outbound ini berjalan sesuai dengan standar kerja. Setelah mendapatkan waktu baku selama 37 menit dari hasil perhitungan maka dilakukan perhitungan jumlah tenaga kerja optimum pada proses outbound untuk menentukan perencanaan kebutuhan tenaga kerja, dengan cara waktu baku dikali dengan beban kerja dan kemudian dibagi dengan waktu kerja efektif yang telah ditetapkan oleh perusahaan. Maka didapatkan penambahan tujuh orang yang semula hanya 5 orang, penambahan tenaga terjadi pada bagian loading ke BTT dan pengecekan kondisi bagasi serta cek manifest bagasi masing - masing yaitu 1 tenaga kerja.
\end{abstract}

Kata Kunci: Outbound Baggage, Operation Management, Time Study

\section{PENDAHULUAN}

Aktifitas yang dilakukan seseorang atau sekelompok orang melalui sistem, prosedur dan metode tertentu dalam rangka memenuhi kebutuhan orang lain disertai kemudahan-kemudahan untuk memenuhi segala kebutuhan mereka salah satunya adalah perusahaan Ground Handling yang melakukan pelayanan darat atau pelayanan di airport. Ground Handling adalah suatu kegiatan airlines yang berkaitan dengan penanganan atau pelayanan terhadap para passanger berikut bagasinya, cargo , pos, peralatan pembantu pergerakan pesawat terbang itu sendiri selama berada di airport, baik departure maupun arrival.

Penelitian ini telah dilakukan pada berbagai unversitas, diantaranya dilakukan oleh Dyah Ika Rinawati, dkk (2012) dengan menggunakan metode Time Study. Trisna Mesra, dkk (2016) dengan menggunakan metode Time Stud. Jurnal yang 
digunakan dalam hal membantu penyelesaian penelitian ini, diantaranya adalah Rosmiani, dkk (2012) mengenai metode Time Study. Gratia dkk (2012) mengenai metode jam henti.

Penelitian yang dilakukan saat ini dengan penelitian yang dilakukan pada tahun - tahun sebelumnya memiliki output yang sama yaitu mengenai keterlambatan pada proses pengeluaran bagasi. Hanya saja kesenjangan penelitian saaat ini dengan penelitian terdahulu adalah yang dahulu tidak dilengkapi dengan alat ukur yang lengkap seperti sekarang yang dilakukan dalam pengukuran serta mengenai analisis kebijakan-kebijakan operasional yang dapat digunakan dalam perusahaan.

\section{METODE PENELITIAN}

(1)Peneltian ini menggunakan berbagai asumsi diantaranya adalah semua proses outbound ini dilakukan dengan tenaga kerja yang sama. Masalah yang diangkat dalam penelitian ini adalah proses pengeluaran bagasi yang memakan waktu lama.

(2)Penelitian ini dilakukan dengan beberapa tahap terlebih dahulu sebelum mendapatkan jawaban dari rumusan masalah yang diangkat. Tahap - tahap tersebut diantaranya adalah:

a) Mulai

Penulis melakukan penelitian dan melihat permasalahan dan kendala yang terjadi pada saat kegiatan praktek kerja lapangan di PT Angkasa Pura II dan hal tersebut menjadi latar belakang permasalahan melakukan penelitian.

b) Merumuskan Masalah

Perumusan masalah dilakukan dengan melakukan pengamatan terlebih dahulu di PT. Angkasa Pura II. Hal ini bertujuan untuk meneliti kembali permasalahan yang dapat dijadikan bahan penelitian. Selanjutnya dapat dirumuskan permasalahan yaitu standar waktu yang dibutuhkan untuk penyelesaian kegiatan dan berapa banyak pekerjaan yang dapat diselesaikan dalam penangan bagasi penumpang pesawat pada proses outbound, sehingga dapat mendukung waktu yang baik dalam setiap aktivitas kegiatan di proses pengeluaran bagasi penumpang.

c) Studi Lapangan

Studi lapangan adalah kegiatan dimana penulis bekerja langsung untuk melakukan penelitian, mengetahui permasalahan yang ada diperusahaan, dan mencari informasi yang berkaitan dengan masalah penelitian serta gambaran secara umum semua kegiatan-kegiatan yang terjadi didalam perusahaan.

d) Studi Pustaka

Studi pustaka dilakukan untuk mendapatkan informasi-informasi penting yang berkaitan dengan penelitian dengan penelitian dan mendukung proses analisis masalah yang akan dilakukan. Selain itu untuk mendapatkan landasan teori yang baik agar penelitian yang dilakukan memliki pedoman dan pola pikir yang logis.

e) Penentuan Tujuan Penelitian

Adapun tujuan dari penelitian ini adalah untuk mengetahui standar waktu kerja setiap kegiatan pada proses outbound. Tujuan yang lain yaitu menetapkan frekuensi pekerjaan yang dapat diselesaikan leh karyawan setiap harinya.

f) Pengumpulan Data

Pengumpulan data dilakukan oleh penulis untuk mencari data-data yang berkaitan dengan permasalahan yang dihadapi. Penelitian dilakukan dengan berada langsung dan mengamati mengamati proses kerja penyelesaian kegiatan outbound di lapangan. Pengumpulan data dilakukan dengan menggunakan perlengkapan yaitu stopwatch, pena, dan kertas. Dan melakukan wawancara langsung kepada karyawan juga menjadi penunjang pengumpulan data dan menambah bahan dalam penelitian.

g) Pengolahaan Data

Pengolahan data dilakukan penulis setelah mengumpulkan data saat melakukan pengamatan. 
h) Analisis dan Pembahasan

Berisikan analisis dan pembahasan terhadap hasil pengolahaan data yang didapat selama proses kegiatan penelitian berlangsung. Pada bagian ini menjawab masalah penelitian atau menunjukan tujuan penelitian yang akan dicap

i) Kesimpulan

Kesimpulan yang diperoleh berdasarkan hasil dari pengolahaan data yang telah dibuat. Penarikan keputusan ini sangat penting dalam memutuskan hasil akhir yang menjawab permasalahan dan merangkum penelitian. Pada akhir penelitian ini diharapkan adanya saran-saran yang sifatnya membangun pada hasil laporan ini yang bersumber dari temuan penelitian.

(3) Metode pengumpulan data, dilakukan dengan beberapa cara yaitu:

a) Observasi Lapangan

Suatu kegiatan yang dilakukan dengan pengamatan langsung terhadap kondisi lingkungan kerja diperusahaan, kemudian dicatat guna mendapatkan data yang diperlukan dalam penelitian.

b) Wawancara

Suatu aktivitas atau interaksi tanya jawab langsung terhadap pihak-pihak tertentu dalam suatu departemen yang terkait dengan objek permasalahan yang diteliti

c) Pengukuran-Pengukuran

Pengukuran dalam penelitian ini dilakukan pada :

- Pengukuran-pengukuran waktu dengan jam henti (stopwatch) dari setiap elemen kerja

- Pengamatan langsung ke bagian penanganan ground handling

Tahapan analisis data dapat dilihat pada flowchart dibawah ini:

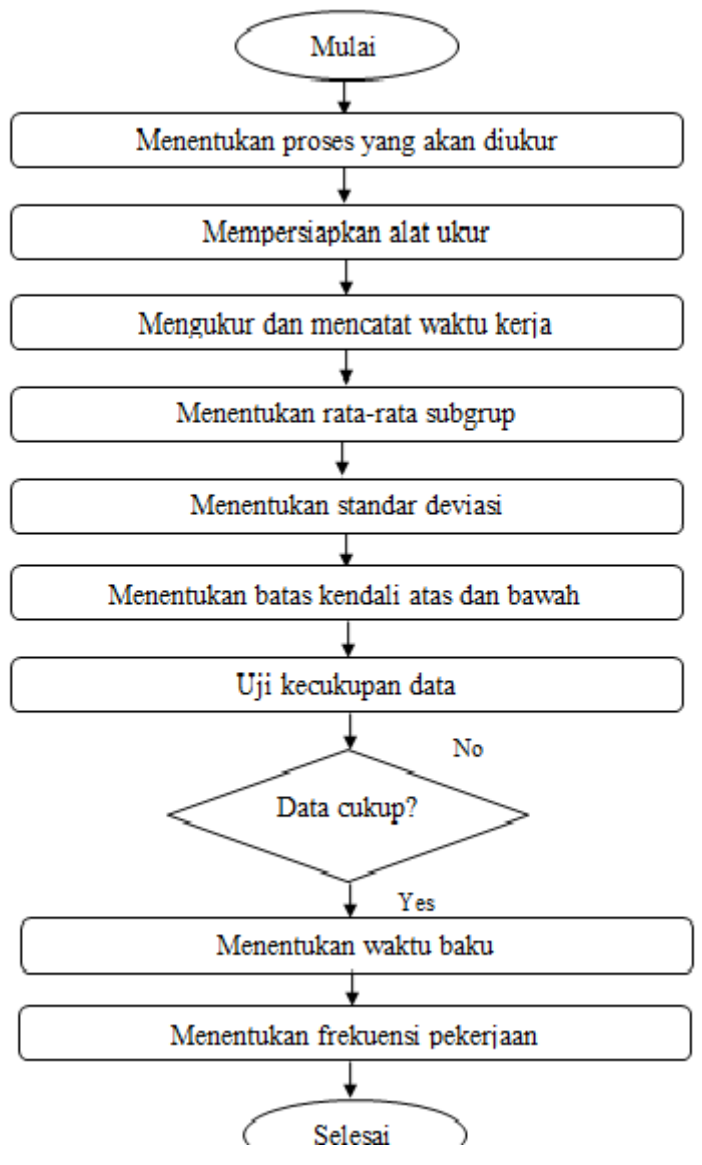

(4) Metodologi penelitian

a) Menentukan proses yang akan diukurLangkah awal dalam melaksanakan penelitian menggunakan metode time study adalah menenetukan proses yang akan diukur. Menentukan proses ini diawali dengan mendefinisikan tugas untuk dipelajari dan diteliti lebih lanjut.

b) Mempersiapkan alat ukur

Langkah berikutnya yaitu dengan mempersiapkan alat ukur. Peralatan yang dibutuhkan dalam melaksanakan aktivitas pengukuran kerja dengan merode time study adalah dengan menggunakan stopwatch, time study board, time study form, dan calculator.

c. Mengukur dan mencatat waktu kerja

Pengukuran waktu kerja dilakukan dengan menggunakan stopwatch dengan mengamati waktu yang dibutuhkan oleh pekerja dalam menyelesaikan pekerjaannya, setelah mengetahui waktu yang dibutuhhkan 
selanjutnya dicatat pada lembar-lembar pengamatan.

d. Menentukan rata-rata subgrup

Rata-rata subgrub ini adalah rata-rata aritmatika atas kali untuk setiap elemenelemen yang diukur atau diteliti dengan menyesuaikan untuk pengaruh yang tidak biasa terjadi untuk setiap elemen.

- Kelompokan hasil pengukuran kedalam beberapa subgrup dan hitung rata-rata dari tiap grup.

$\bar{x}=\frac{\sum x_{i}}{k}$.

e. Menentukan standar deviasi

Menentukan standar deviasi berfungsi untuk menentukan bagaimana sebaran data dalam sampel dan seberapa dekat titik data individu ke mean atau rata-rata nilai sampel.

$\sigma=\sqrt{\frac{\sum\left(\mathrm{x}_{\mathrm{j}}-\overline{\mathrm{x}}\right)^{2}}{\mathrm{~N}-1}}$.

f. Menentukan batas kendali atas dan bawah

Batas kendali atas dan bawah ini digunakan untuk mengetahui segala kondisi yang tidak wajar. Apabila terdapat data yang kondisi dianggap tidak wajar tidak perlu dimasukkan dalam proses Analisa.

$B K A=\bar{x}+3 \sigma_{\bar{x}}$

$B K B=\bar{x}-3 \sigma_{\bar{x}}$

g. Uji kecukupan data

Uji kecukupan data dilakukan untuk mengetahui data pengukuran yang telah diamati cukup untuk melaksanakan penelitian. Untuk mengukur uji kecukupan data dapat dilihat pada rumus 2.7. Apabila N' lebih besar dari N, maka harus dilakukan pengukuran kembali agar jumlah pengukuran cukup untuk diolah, tetapi apabila N' lebih kecil dari atau sama dengan $\mathrm{N}$ maka tidak perlu dilakukan penambahan pengukuran.

$\boldsymbol{N}^{\prime}=\left(\frac{k / s \sqrt{N \sum x_{j}{ }^{2}-\left(\sum x_{j}\right)^{2}}}{\sum x_{j}}\right)^{2}$

h. Menghitung waktu siklus

Waktu siklus adalah waktu penyelesaian rata-rata selama pengukuran. Cara untuk menghitung waktu siklus menurut Sutalaksana (2006)

$W_{s}=\frac{\sum x_{j}}{N}$. i. Menghitung waktu normal

Waktu normal adalah waktu yang dibutuhkan secara wajar oleh karyawan untuk menyelesaikan pekerjaan. Tujuannya untuk mendapatkan waktu siklus rata-rata yang wajar. Cara menghitung waktu normal menurut Sutalaksana (2006)

$\mathrm{W}_{n}=\mathrm{W}_{S} \times \mathrm{p}$

j. Menghitung waktu baku

Waktu baku berfungsi sebagai perencanaan waktu dan jumlah pekerja yang harus dipekerjakan pada bagian atau proses-proses tertentu agar produktivitas perusahaan meningkat.

$\mathrm{W}_{b}=\mathrm{W}_{n}(1+l)$

k. Menentukan frekuensi pekerjaan

Hal ini bertujuan untuk mengetahui seberapa banyak pekerjaan yang bisa diselesaikan oleh karyawan setiap harinya. Banyaknya pekerjaan ditentukan dengan melakukan perbandingan jam kerja efektif dengan waktu baku yang telah ditentukan

Frekuensi Pekerjaan $=\frac{\text { Jam Kerja Efektif }}{\text { Waktu Baku }}$.

1. Menentukan jumlah tenaga kerja

Setelah perhitungan frekuensi pekerja diperoleh, langkah selanjutnya adalah menentukan jumlah tenaga kerja optimum pada setiap kegiatan yang dilakukan oleh bagian ground handling.

Tenaga Kerja $=\frac{\text { Waktu Baku } \times \text { Output }}{\text { Waktu Kerja }}$

\section{HASIL DAN PEMBAHASAN}

Data yang dianalisis dalam penelitian ini adalah data pengamatan yang dilakukan oleh penulis. Kemudian dilakukan perhitungan data pengamatan untuk setiap kegiatan outbound bagasi yang dapat dilihat pada tabel 1 . 
Tabel 1. Data Hasil Pengamatan

\begin{tabular}{|c|c|c|c|c|c|}
\hline \multirow{2}{*}{$\begin{array}{l}\text { Banyaknya } \\
\text { Pengamatan }\end{array}$} & \multicolumn{4}{|c|}{$\begin{array}{c}\text { Kegiatan } \\
\text { Pengamatan (Menit) }\end{array}$} & \multirow{2}{*}{$\begin{array}{c}\text { Total } \\
\text { Seluruh } \\
\text { Kegiatan }\end{array}$} \\
\hline & 1 & 2 & 3 & 4 & \\
\hline 1 & 9,11 & 8,3 & 3,21 & 8,19 & 28,81 \\
\hline 2 & 10,6 & 8,32 & 3,29 & 8,12 & 30,33 \\
\hline 3 & 9,13 & 8,2 & 3,45 & 8,41 & 29,19 \\
\hline 4 & 9,22 & 8,47 & 3,16 & 8,1 & 28,95 \\
\hline 5 & 9,34 & 10,4 & 2,43 & 8,46 & 30,63 \\
\hline 6 & 10,2 & 8,33 & 3,34 & 8,51 & 30,38 \\
\hline 7 & 8,37 & 7,3 & 3,16 & 7,53 & 26,36 \\
\hline 8 & 9,11 & 8,3 & 3,21 & 8,19 & 28,81 \\
\hline 9 & 8,24 & 9,4 & 2,56 & 8,46 & 28,66 \\
\hline 10 & 9,11 & 8,3 & 3,31 & 8,19 & 28,91 \\
\hline 11 & 9,07 & 9,25 & 3,15 & 8,6 & 30,07 \\
\hline 12 & 7,39 & 7,35 & 3,43 & 7,48 & 25,65 \\
\hline 13 & 7,42 & 7,49 & 3,4 & 6,3 & 24,61 \\
\hline 14 & 8,51 & 7,44 & 2,39 & 8,21 & 26,55 \\
\hline 15 & 9,46 & 8,43 & 3,27 & 8,4 & 29,56 \\
\hline 16 & 8,47 & 7,5 & 3,7 & 8,3 & 27,97 \\
\hline 17 & 10,8 & 8,36 & 3,2 & 8,45 & 30,81 \\
\hline 18 & 8,52 & 8,39 & 3,11 & 8,5 & 28,52 \\
\hline 19 & 8,37 & 7,32 & 3,16 & 7,53 & 26,38 \\
\hline 20 & 8,47 & 7,56 & 3,37 & 8,3 & 27,70 \\
\hline Rata-Rata & 8,94 & 8,22 & 3,16 & 8,11 & 28,44 \\
\hline
\end{tabular}

Keterangan kegiatan :

1) Bongkar muat bagasi penumpang pesawat,

2) Loading ke BTT (Baggage Towing Tracto)

3) Perjalanan dari landasan pacu menuju apron gedung bandara.

4) Pengecekan kondisi bagasi dan cek manifest bagasi penumpang.

Maka langkah selanjutnya adalah mengelompokan data hasil pengamatan kedalam subgrup-subgrup yang masing-masing berisi 4 data pengukuran yang diperoleh secara berturut-turut beserta harga rataratanya.

\section{Menghitung Harga Rata-rata dari Subgrup}

Hasil pengelompokan subgrup untuk aktivitas Bongkar Muat Bagasi Penumpang jumlah harga rata-rata nya sebesar 45 menit. Harga rata-rata yang memiliki durasi tertinggi yaitu berada pada subgrup ke-1 dengan durasi waktu 9,76 menit. Dengan cara perhitungan yang sama maka akan diperoleh hasil yang sama untuk kegiatan yang lainnya. Adapun hasil perhitungan rata-rata dari harga rata-rata subgrup untuk kegiatan yang lain dapat dilihat pada Tabel 2.

\section{Tabel 2 Hasil Perhitungan Dari Rata-Rata Subgrup}

\begin{tabular}{|c|l|c|}
\hline $\begin{array}{c}\text { Kegiatan } \\
\text { ke- }\end{array}$ & \multicolumn{1}{|c|}{ Kegiatan } & $\begin{array}{c}\text { Hasil Perhitungan } \\
\text { Rata-rata dari } \\
\text { Rata-rata Subgrup }\end{array}$ \\
\hline 1 & $\begin{array}{l}\text { Bongkar Muat Bagasi } \\
\text { Penumpang Pesawat }\end{array}$ & 9 menit \\
\hline 2 & $\begin{array}{l}\text { Loading ke BTT (Baggage } \\
\text { Towing Tracto) }\end{array}$ & 8,22 Menit \\
\hline 3 & $\begin{array}{l}\text { Perjalanan Dari Landasan } \\
\text { Pacu ke Apron Gedung } \\
\text { Bandara }\end{array}$ & 3,16 Menit \\
\hline 4 & $\begin{array}{l}\text { Pengecekan Kondisi } \\
\text { Bagasi dan Cek Manifest } \\
\text { Bagasi dan Peletakan ke } \\
\text { Conyevor }\end{array}$ \\
\hline
\end{tabular}

Menetukan Standar Deviasi Sebenarnya dari Waktu Penyelesaian

Dengan cara perhitungan yang sama maka akan diperoleh hasil yang sama untuk kegiatan yang lainnya. Adapun hasil perhitungan hasil perhitungan standar deviasi sebenarnya dari waktu penyelesaian untuk kegiatan yang lain dapat dilihat pada Tabel

Tabel 3 Hasil Perhitungan Standar Deviasi

\begin{tabular}{|c|l|c|}
\hline $\begin{array}{c}\text { Kegiatan } \\
\text { ke- }\end{array}$ & \multicolumn{1}{|c|}{ Kegiatan } & $\begin{array}{c}\text { Hasil Perhitungan } \\
\text { Standar deviasi } \\
\text { Sebenarnya dari } \\
\text { Waktu } \\
\text { Penyelesaian }\end{array}$ \\
\hline 1 & $\begin{array}{l}\text { Bongkar Muat Bagasi } \\
\text { Penumpang Pesawat }\end{array}$ & 0,94 menit \\
\hline 2 & $\begin{array}{l}\text { Loading ke BTT } \\
\text { Baggage Towing } \\
\text { Tracto) }\end{array}$ & 0,90 menit \\
\hline 3 & $\begin{array}{l}\text { Perjalanan Dari } \\
\text { Landasan Pacu ke }\end{array}$ & 0,33 menit \\
\hline
\end{tabular}




\begin{tabular}{|l|l|l|}
\hline & Apron Gedung Bandara & \\
\hline \multirow{4}{*}{4} & $\begin{array}{l}\text { Pengecekan Kondisi } \\
\text { Bagasi dan Cek } \\
\text { Manifest Bagasi dan } \\
\text { Peletakan ke Conyevor }\end{array}$ & 0,53 menit \\
\hline
\end{tabular}

\section{Menentukan Standar Deviasi dari Distribusi Harga Rata-rata Subgrup}

Dengan cara perhitungan yang sama maka akan diperoleh hasil yang sama untuk kegiatan yang lainnya. Adapun hasil perhitungan simpangan baku dari ditribusi harga rata-rata subgrup untuk kegiatan yang lain dapat dilihat pada Tabel

Tabel 4 Hasil Perhitungan Standar Deviasi Dari Harga Rata-Rata Subgrup

\begin{tabular}{|c|c|c|}
\hline $\begin{array}{c}\text { Kegiatan } \\
\text { ke- }\end{array}$ & Kegiatan & $\begin{array}{c}\text { Hasil Perhitungan } \\
\text { Standar Deviasi dari } \\
\text { Distribusi Rata-rata } \\
\text { Subgrup }\end{array}$ \\
\hline 1 & $\begin{array}{c}\text { Bongkar Muat Bagasi } \\
\text { Penumpang Pesawat }\end{array}$ & 0,18 menit \\
\hline 2 & $\begin{array}{c}\text { Loading ke BTT } \\
\text { (Baggage Towing } \\
\text { Tracto) }\end{array}$ & 0,18 menit \\
\hline 3 & $\begin{array}{c}\text { Perjalanan Dari } \\
\text { Landasan Pacu ke } \\
\text { Apron Gedung Bandara }\end{array}$ & 0,06 menit \\
\hline 4 & $\begin{array}{c}\text { Pengecekan Kondisi } \\
\text { Bagasi dan Cek } \\
\text { Manifest Bagasi dan } \\
\text { Peletakan ke Conyevor }\end{array}$ & 0,10 menit \\
\hline
\end{tabular}

\section{Menghitung Batas Kendali Atas (BKA) dan Batas Kendali Bawah (BKB)}

Seluruh aktivitas kegiatan dari proses outbound bagasi akan dituangkan dalam diagram kendali sebagai berikut.

1. Bongkar muat bagasi penumpang pesawat

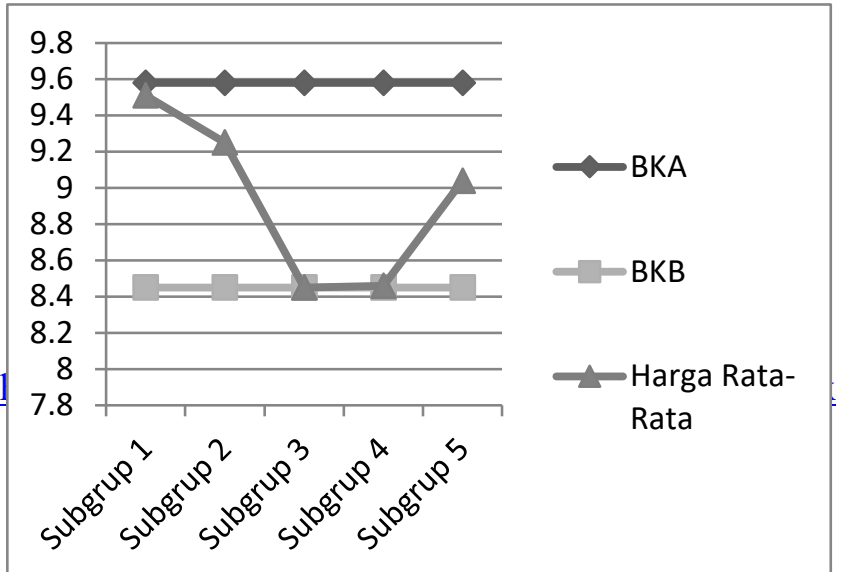

\section{Gambar 1 Diagram Kendali Bongkar Muat Bagasi Penumpang Pesawat}

Dari Diagram Kendali untuk aktivitas Bongkar muat bagasi penumpang pesawat diatas Batas Kendali Atas (BKA) berada pada waktu 9,58 menit sedangkan untuk Batas Kendali Bawah (BKB) berada pada waktu 8,45 menit. Harga Rata-Rata untuk aktivitas Bongkar muat bagasi penumpang pesawat berada dalam Batas Kendali Atas (BKA) dan Batas Kendali Bawah (BKB) dengan sebaran yang stabil berada diantara 8 hingga 9,5 menit. Harga rata-rata tertinggi berada pada subgrup ke-1

\section{Loading ke BTT (Baggage Towing Tracto)}

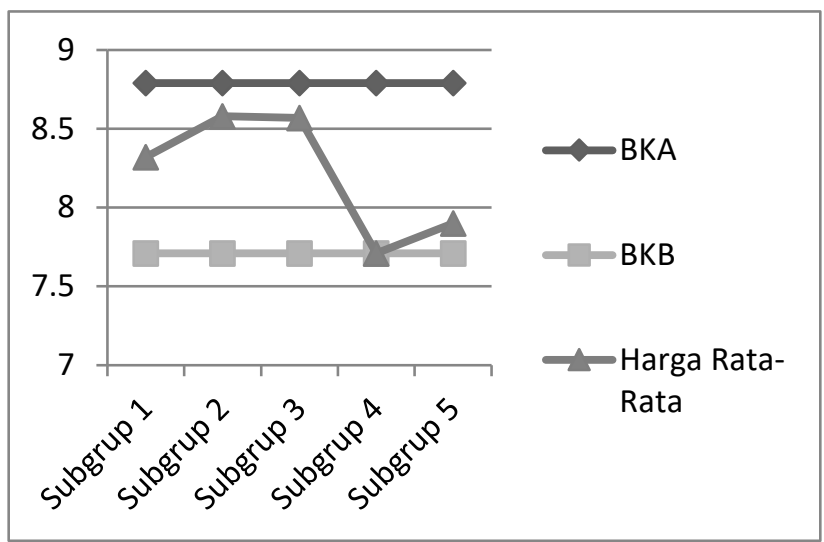

Gambar 2 Diagram Kendali Loading ke BTT (Baggage Towing Tracto)

Pada Diagram Kendali untuk aktivitas Loading ke BTT (Baggage Towing Tracto) diatas Batas Kendali Atas (BKA) berada pada waktu 8,76 menit menit sedangkan untuk Batas Kendali Bawah (BKB) berada pada waktu 7,68 menit. Harga Rata-Rata untuk aktivitas Baggage Towing Tracto) dalam Batas Kendali Atas (BKA) dan Batas Kendali Bawah (BKB). Harga rata-rata subgrup menunjukan waktu yang fluktuatif. 
3. Perjalanan Dari Landasan Pacu ke Apron Gedung Bandara

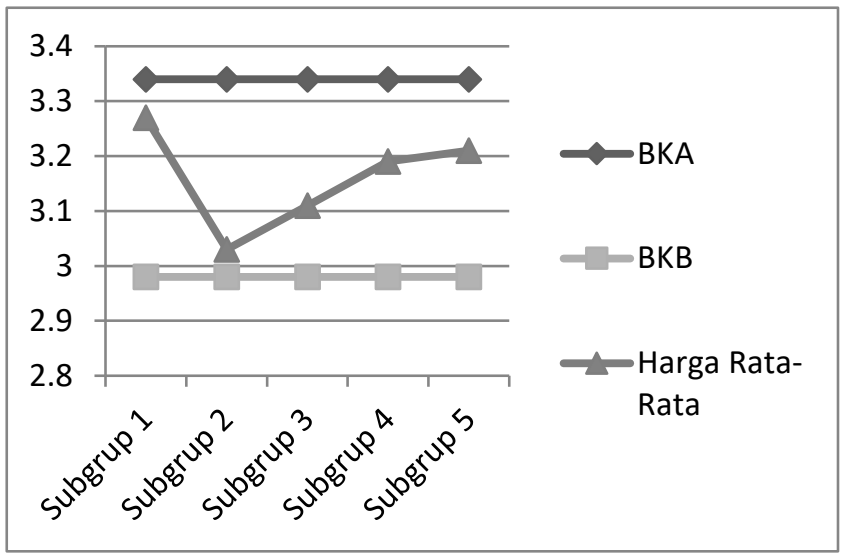

Gambar 3 Diagram Kendali Perjalanan Dari Landasan Pacu ke Apron Gedung Bandara

Pada Diagram Kendali untuk aktivitas Perjalanan dari landasan pacu ke gedung bandara diatas Batas Kendali Atas (BKA) berada pada waktu 3,34 menit sedangkan untuk Batas Kendali Bawah (BKB) berada pada waktu 2,98 menit. Harga Rata-Rata untuk aktivitas Perjalanan dari landasan pacu ke gedung bandara berada dalam Batas Kendali Atas (BKA) dan Batas Kendali Bawah (BKB). Harga rata-rata subgrup menunjukan waktu yang fluktuatif.

4. Pengecekan Kondisi Bagasi, Cek Manifest Bagasi dan Peletakan ke Conyevor

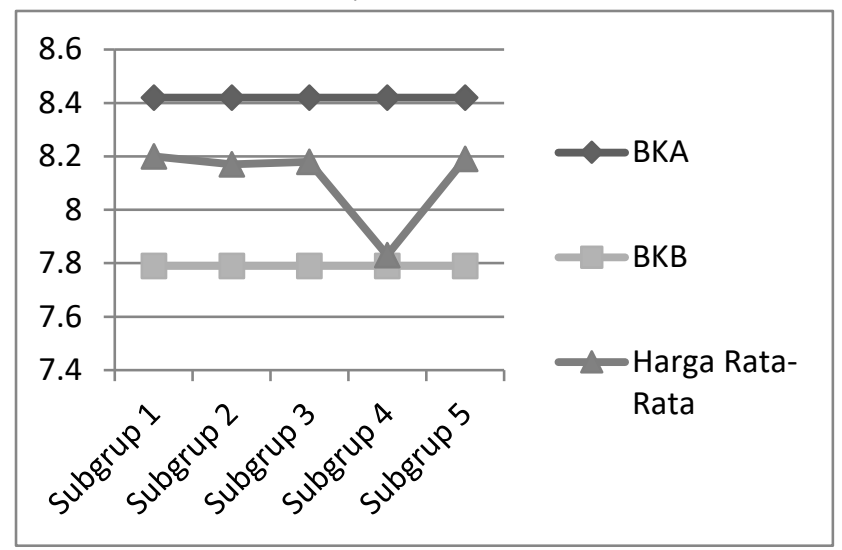

Gambar 4 Diagram Kendali Pengecekan Kondisi Bagasi, Cek Manifest Bagasi dan Peletakan ke Conyevor

Pada Diagram Kendali untuk aktivitas Pengecekan Kondisi Bagasi dan Cek Manifest Bagasi dan Peletakan ke conyevor diatas Batas Kendali Atas
(BKA) berada pada waktu 8,42 menit menit sedangkan untuk Batas Kendali Bawah (BKB) berada pada waktu 7,79 menit. Harga Rata-Rata untuk aktivitas Pengecekan Kondisi Bagasi dan Cek Manifest Bagasi dan Peletakan ke conyevor berada dalam Batas Kendali Atas (BKA) dan Batas Kendali Bawah (BKB). Harga rata-rata subgrup menunjukan waktu yang fluktuatif.

Dengan cara perhitungan yang sama maka akan diperoleh hasil untuk kegiatan yang lainnya. Adapun hasil perhitungan Batas Kendali Atas dan Batas Kendali Bawah untuk kegiatan yang lain dapat dilihat pada Tabel 5.

Tabel 5 Menentukan BKA Dan BKB

\begin{tabular}{|c|l|c|c|c|}
\hline $\begin{array}{c}\text { Kegiatan } \\
\text { ke- }\end{array}$ & \multicolumn{1}{|c|}{ Kegiatan } & BKA & BKB & Keterangan \\
\hline 1 & $\begin{array}{l}\text { Bongkar Muat } \\
\text { Bagasi } \\
\text { Penumpang } \\
\text { Pesawat }\end{array}$ & 9,58 & 8,45 & Terkendali \\
\hline 2 & $\begin{array}{l}\text { Loading Bagasi } \\
\text { Penumpang ke } \\
\text { Mobil Gerobak } \\
\text { Ground } \\
\text { Handling }\end{array}$ & 8,76 & 7,68 & Terkendali \\
\hline 3 & $\begin{array}{l}\text { Perjalanan Dari } \\
\text { Landasan Pacu } \\
\text { ke Apron } \\
\text { Gedung } \\
\text { Bandara }\end{array}$ & 3,34 & 2,98 & Terkendali \\
\hline 4 & $\begin{array}{l}\text { Pengecekan } \\
\text { Kondisi Bagasi } \\
\text { dan Cek } \\
\text { Manifest Bagasi } \\
\text { dan Peletakan } \\
\text { ke Conyevor }\end{array}$ & 8,42 & 7,79 & Terkendali \\
\hline
\end{tabular}

\section{Melakukan Uji Kecukupan Data}

Dengan cara perhitungan yang sama maka akan diperoleh hasil untuk kegiatan yang lainnya. Adapun hasil perhitungan Uji Kecukupan Data untuk kegiatan yang lain dapat dilihat pada Tabel 6 .

\section{Tabel 6 Melakukan Uji Kecukupan Data}

\begin{tabular}{|l|l|c|l|}
\hline Kegiatan ke- & Kegiatan & $\begin{array}{c}\text { Uji } \\
\text { Kecukupan } \\
\text { Data }\end{array}$ & Keterangan \\
\hline
\end{tabular}




\begin{tabular}{|c|l|c|c|}
\hline 1 & $\begin{array}{l}\text { Bongkar Muat } \\
\text { Bagasi } \\
\text { Penumpang } \\
\text { Pesawat }\end{array}$ & 8 Data & Cukup \\
\hline 2 & $\begin{array}{l}\text { Loading Bagasi } \\
\text { Penumpang ke } \\
\text { Mobil Gerobak } \\
\text { Ground } \\
\text { Handling }\end{array}$ & 6 Data & Cukup \\
\hline 3 & $\begin{array}{l}\text { Perjalanan Dari } \\
\text { Landasan Pacu } \\
\text { ke Apron } \\
\text { Gedung Bandara }\end{array}$ & 3 Data & Cukup \\
\hline 4 & $\begin{array}{l}\text { Pengecekan } \\
\text { Kondisi Bagasi } \\
\text { dan Cek } \\
\text { Manifest Bagasi } \\
\text { dan Peletakan ke } \\
\text { Conyevor }\end{array}$ & 8 Data & Cukup \\
\hline
\end{tabular}

\section{Menentukan Waktu Siklus (Ws)}

Dengan cara perhitungan yang sama maka akan diperoleh hasil untuk kegiatan yang lainnya. Sehingga didapatkan waktu siklus untuk masingmasing kegiatan dapat dilihat pada tabel 7.

Tabel 6 Perhitungan Waktu Siklus

\begin{tabular}{|c|l|c|}
\hline $\begin{array}{c}\text { Kegiatan } \\
\text { ke- }\end{array}$ & \multicolumn{1}{|c|}{ Kegiatan } & $\begin{array}{c}\text { Waktu } \\
\text { Siklus } \\
\text { (Ws) }\end{array}$ \\
\hline 1 & $\begin{array}{l}\text { Bongkar Muat Bagasi } \\
\text { Penumpang Pesawat }\end{array}$ & 9 menit \\
\hline 2 & $\begin{array}{l}\text { Loading ke BTT (Baggage } \\
\text { Towing Tracto) }\end{array}$ & 8 menit \\
\hline 3 & $\begin{array}{l}\text { Perjalanan Dari Landasan Pacu } \\
\text { ke Apron Gedung Bandara }\end{array}$ & 3 menit \\
\hline 4 & $\begin{array}{l}\text { Pengecekan Kondisi Bagasi } \\
\text { dan Cek Manifest Bagasi dan } \\
\text { Peletakan ke Conyevor }\end{array}$ & 8 menit \\
\hline TOTAL & \multicolumn{2}{|c|}{\begin{tabular}{c} 
Menit \\
\hline
\end{tabular}}
\end{tabular}

\section{Menentukan Waktu Normal (Wn)}

Dengan cara perhitungan yang sama maka akan diperoleh hasil untuk kegiatan yang lainnya. Sehingga didapatkan waktu normal untuk masingmasing kegiatan dapat dilihat pada table 8 .
Tabel 8. Perhitungan Waktu Normal

\begin{tabular}{|l|c|}
\hline \multicolumn{1}{|c|}{ Kegiatan } & Waktu Normal \\
\hline $\begin{array}{l}\text { Bongkar Muat Bagasi Penumpang } \\
\text { Pesawat }\end{array}$ & 8,55 menit \\
\hline $\begin{array}{l}\text { Loading ke BTT (Baggage Towing } \\
\text { Tracto) }\end{array}$ & 8 menit \\
\hline $\begin{array}{l}\text { Perjalanan Dari Landasan Pacu ke } \\
\text { Apron Gedung Bandara }\end{array}$ & 2,91 menit \\
\hline $\begin{array}{l}\text { Pengecekan Kondisi Bagasi, Cek } \\
\text { Canifest Bagasi dan Peletakan ke }\end{array}$ & 8,24 menit \\
\hline TOTAL & 27,70 menit \\
\hline
\end{tabular}

\section{Menentukan Waktu Baku (Wb)}

Setelah menghitung Waktu Sikulus dan Waktu Normal, maka langkah terakhir yaitu menghitung Waktu Baku untuk setiap aktivitas outbound bagasi.

Dengan cara perhitungan yang sama maka akan diperoleh hasil untuk kegiatan yang lainnya. Sehingga didapatkan waktu normal untuk masingmasing kegiatan dapat dilihat pada tabel 9.

Tabel 9 Perhitungan Waktu Baku

\begin{tabular}{|l|c|}
\hline \multicolumn{1}{|c|}{ Kegiatan } & Waktu Baku \\
\hline $\begin{array}{l}\text { Bongkar Muat Bagasi Penumpang } \\
\text { Pesawat }\end{array}$ & 11,45 Menit \\
\hline $\begin{array}{l}\text { Loading ke BTT (Baggage Towing } \\
\text { Tracto) }\end{array}$ & 10,72 Menit \\
\hline $\begin{array}{l}\text { Perjalanan Dari Landasan Pacu ke } \\
\text { Apron Gedung Bandara }\end{array}$ & 3,66 Menit \\
\hline $\begin{array}{l}\text { Pengecekan Kondisi Bagasi dan Cek } \\
\text { Manifest Bagasi dan Peletakan ke } \\
\text { Conyevor }\end{array}$ & 11 Menit \\
\hline TOTAL & 36,83 Menit \\
\hline
\end{tabular}

\section{Menentukan Frekuensi Pekerjaan}

Hasil perhitungan frekuensi yang penulis lakukan diperoleh dari jam efektif kerja pekerja dibagi dengan waktu baku setiap aktivitasnya masingmasing. Jam efektif kerja dari pekerja yaitu 480 menit. 
Tabel 10. Perhitungan frekuensi pekerjaan

\begin{tabular}{|l|c|}
\hline \multicolumn{1}{|c|}{ Aktivitas } & $\begin{array}{c}\text { Frekuensi } \\
\text { Pekerjaan }\end{array}$ \\
\hline Bongkar Muat Bagasi Penumpang Pesawat & 42 Kali \\
\hline Loading ke BTT (Baggage Towing Tracto) & 45 Kali \\
\hline $\begin{array}{l}\text { Perjalanan Dari Landasan Pacu ke Apron } \\
\text { Gedung Bandara }\end{array}$ & 131 Kali \\
\hline $\begin{array}{l}\text { Pengecekan Kondisi Bagasi, Cek Manifest } \\
\text { Bagasi dan Peletakan ke Conyevor }\end{array}$ & 44 Kali \\
\hline
\end{tabular}

\section{Menentukan Jumlah Tenaga Kerja Optimum}

Setelah Menentukan pengukuran frekuensi kerja diperoleh, lamgkah selanjutnya adalah menentukan jumlah tenaga kerja optimum pada setiap kegiatan yang dilakukan oleh bagian groound handling. Hal ini bertujuan untuk mengetahui seberapa banyak tenaga kerja yang dibutuhkan setiap harinya.

\section{Tabel 11. Perhitungan Tenaga Kerja Optimum}

\begin{tabular}{|c|c|c|c|}
\hline No & Aktivitas & $\begin{array}{l}\text { Jumlah } \\
\text { Tenaga } \\
\text { Kerja } \\
\text { Awal }\end{array}$ & $\begin{array}{l}\text { Jumlah } \\
\text { Tenaga } \\
\text { Kerja } \\
\text { Tambahan }\end{array}$ \\
\hline 1 & $\begin{array}{l}\text { Bongkar Muat Bagasi } \\
\text { Penumpang Pesawat }\end{array}$ & 2 & 2 \\
\hline 2 & $\begin{array}{l}\text { Loading ke BTT (Baggage } \\
\text { Towing Tracto) }\end{array}$ & 1 & 2 \\
\hline 3 & $\begin{array}{l}\text { Perjalanan Dari Landasan } \\
\text { Pacu ke Apron Gedung } \\
\text { Bandara }\end{array}$ & 1 & 1 \\
\hline 4 & $\begin{array}{l}\text { Pengecekan Kondisi } \\
\text { Bagasi dan Cek Manifest } \\
\text { Bagasi dan Peletakan ke } \\
\text { Conyevor }\end{array}$ & 1 & 2 \\
\hline
\end{tabular}

Dengan demikian setelah dilakukan perhitungan maka dapat dihasilkan penambahan tenaga kerja yang awalnya hanya 5 orang kini menjadi 7 orang. Penambahan tersebut terjadi pada proses loading ke BTT dan Pengecekan kondisi bagasi, cek manifest bagasi dan peletakan ke conveyor.

\section{KESIMPULAN}

Berdasarkan hasil penelitian dan pengolahan data, waktu baku untuk proses outbound bagasi membutuhkan waktu 37 menit. Sebelum menghitung waktu baku terlebih dahulu dilakukan perhitungan waktu siklus dan waktu normal. Waktu siklus merupakan waktu penyelesaian rata-rata pekerjaan maka waktu siklus untuk proses outbound bagasi yaitu 28 menit. Sebelum menghitung waktu normal terlebih dahulu menentukan faktor penyesuaian dengan menggunakan metode Westinghouse yang memperhatikan keterampilan, usaha, kondisi kerja, konsistensi serta ketelitian dan tingkat kesulitan. Setelah dilakukan perhitungan maka diperoleh nilai waktu normal untuk proses outbound bagasi yaitu 27,70 menit. Untuk mendapatkan waktu baku dibutuhkan faktor kelonggaran (allowance) yang diberikan sesuai dengan kebutuhan sehingga faktor kelonggaran ini disesuaikan dengan kondisi pekerja dan lingkungan sekitar pekerja. Faktor penyesuaian dan kelonggaran merupakan asumsi objektif penulis yang disesuaikan dengan kondisi pekerja dilapangan.

Pada setiap proses dalam menyelesaikan proses outbound memerlukan waktu yang berbeda karena aktivitas yang dilakukan berbeda-beda Pada aktivitas ke-1 melakukan proses Bongkar Muat Bagasi Penumpang Pesawat waktu baku yang dihasilkan adalah 11,45 menit. Pada aktivitas ke-2 Loading ke BTT (Baggage Towing Tracto) waktu baku yang dibutuhkan yaitu 10,72 menit. Aktivitas ini melakukan penyusunan bagasi diatas BTT dengan rapih dan sesuai dengan karakteristik bagasi. Aktivitas ke-3 Perjalanan Dari Landasan Pacu ke Apron Gedung Bandara waktu baku yang dibutuhkan yaitu 3,66 menit. Aktivitas ke-4 Pengecekan Kondisi Bagasi, Cek Manifest Bagasi dan Peletakan ke Conyevor waktu baku yang dibutuhkan yaitu 11 menit.

Setelah mendapatkan waktu baku selama 37 menit dari hasil perhitungan maka dilakukan perhitungan jumlah tenaga kerja optimum pada proses outbound untuk menentukan perencanaan kebutuhan tenaga kerja, dengan cara waktu baku dikali dengan beban kerja dan kemudian dibagi dengan waktu kerja efektif yang telah ditetapkan oleh perusahaan. Maka didapatkan penambahan tujuh orang yang semula hanya 5 orang, penambahan tenaga terjadi pada bagian loading ke BTT dan pengecekan kondisi bagasi serta cek manifest bagasi masing - masing yaitu 1 tenaga kerja. Perusahaan mengalami kekurangan tenaga kerja sebanyak dua orang, ini merupakan salah satu penyebab lambannya proses dari pengeluaran bagasi di bandara Husein Sastranegara Bandung. 


\section{REFERENSI}

Penulisan naskah dan sitasi yang diacu dalam naskah ini disarankan menggunakan aplikasi referensi diantaranya adalah:

Jurnal:

1) Rinawati, Ika dkk. (2012) Penentuan waktu standar dan jumlah kerja optimal. Jurnal TI UNDIP Vol VII (143-150)

2) Nevi Viliyanti, Endah Rahayu Lestari, Sakunda Anggraini (2013). Analisis pengukuran waktu kerja. Jurnal Industri UNBRAW Vol 4 No 1 Halaman 66-73.

3) Gratia Utomo, (2015). Analisis Perhitungan Waktu Baku Menggunakan Metode Jam Henti. Jurnal Pasti Universitas Al AzharVol XII No 2 169-183.

4) Trisna Mesra, Ludi Susanti. (2016). Evaluasi Shift Kerja Dan Penentuan Waktu Standar. Jurnal Sistem Industri Universitas Andalas Vol 15 No 16-32.

5) A.P. Puvanasvaran, C.Z. Mei, V.A. Alagendran (2013). Peningkatan Efisiensi Peralatan Keseluruhan Dari Proses Autoklaf Melalui Studi Waktu.

\section{Texbooks:}

1) Wignjosoebroto, Sritomo.. Egronomi Studi Gerak Dan Waktu. Surbaya : Penerbit Guna Widya. 2018 73-90

2) Sutalaksana, Iftikar $Z$ dkk.. Teknik Perancangan Sistem Kerja. Bandung: Penerbit ITB. 2016. $119-130$ 